\title{
Trend of HIV seroprevalence among antenatal women at tertiary care hospital in North India, eleven years retrospective study
}

\author{
Seema Dwivedi $^{1}$, Uruj Jahan ${ }^{1 *}$, Roli Srivastava ${ }^{2}$, Anshu Agnihotri ${ }^{1}$
}

\author{
${ }^{1}$ Department of Obstetrics and Gynecology, GSVM Medical College, Kanpur, Uttar Pradesh, India \\ ${ }^{2}$ Department of Paediatrics, GSVM Medical College, Kanpur, Uttar Pradesh, India
}

Received: 19 November 2016

Accepted: 13 December 2016

\author{
*Correspondence: \\ Dr. Uruj Jahan, \\ E-mail: druruj@gmail.com
}

Copyright: (c) the author(s), publisher and licensee Medip Academy. This is an open-access article distributed under the terms of the Creative Commons Attribution Non-Commercial License, which permits unrestricted non-commercial use, distribution, and reproduction in any medium, provided the original work is properly cited.

\section{ABSTRACT}

Background: Human Immunodeficiency virus (HIV)/Acquired immunodeficiency syndrome (AIDS) is spreading worldwide at an alarming rate and India has third largest number of estimated people living with HIV/AIDS in the world. Estimating the HIV seroprevalence in a low risk population such as pregnant women provide essential information for monitoring trend of HIV in general population and assist in prevention from mother to child transmission (PMTCT) of HIV infection. Only few studies are available from this part of northern India. So we carried out this study to find out seroprevalence of HIV in pregnant women at tertiary care hospital of Uttar Pradesh, India.

Methods: Blood samples were collected from pregnant women attending antenatal clinic of GSVM Medical college, Kanpur, U.P, India. after pretest counseling and inform consent from September 2005 to July 2016. The samples are tested as per National AIDS Control Organization (NACO) guidelines.

Results: Among 38794 pregnant women counseled, 34924(90.02\%) accepted HIV testing. 102 women out of 34924 were found HIV seropositive with prevalence rate of $0.3 \%$. Among seropositive women, majority were Hindu $(88.2 \%)$, housewife $(89.2 \%)$, multigravida $(62.7 \%)$, studied up to primary or secondary $(78.4 \%)$, of low socioeconomic status $(74.5 \%)$ and belongs to rural area $(67.6 \%)$. Majority of HIV seropositive (34.3\%) women were in age group of 25-30 years followed by 21-25years (25.4\%). HIV seroprevalence rates showed an increasing trend from $0.14 \%$ in 2006 to $0.49 \%$ in 2016 (till July).

Conclusions: Seroprevalence of HIV infection amongst antenatal women was $0.3 \%$ in past 11 years which is in increasing trend in contrast to other studies and slightly higher than national projection $(0.29 \%)$. It concludes that it is right time to strengthen prevention of mother to child transmission (PMTCT) services by joint efforts of the private and public sectors.

Keywords: AIDS, HIV, Pregnant women, PMTCT, Seroprevalence

\section{INTRODUCTION}

HIV/AIDS is spreading worldwide at an alarming rate. The first AIDS case was reported in 1986 in India and India is categorized as a low prevalence nation for HIV with seroprevalence rate of less than $1 \%$ among adult population. But India has third largest number of estimated people living with HIV/AIDS in the world. There are an estimated 21.17 lakhs people living with
HIV/AIDS of which $6.54 \%$ are children ( $<15$ years) with an adult prevalence of $0.26 \%$ in $2015 .^{1}$ The incidence of infection especially in sexually active group is the most sensitive marker to track the course of HIV epidemic. Unfortunately, incidence is hard to measure, but prevalence in young women is indirect but useful tool. ${ }^{2}$ Accordingly, HIV data from antenatal women has been used to monitor trend in the general population and to predict seroprevalence in young children., 
The predominant mode of HIV transmission is through hetero sexual contact, therefore women are at high risk of getting infection. ${ }^{5}$ The transmission of HIV from infected mother to infant ranges from $25 \%-35 \%$ which accounts for $4 \%$ of the total HIV infection in India. ${ }^{6}$ Hence, mother to child transmission is by far the most significant route of transmission of HIV infection in children below the age of 15 years. $^{7}$ So in NACP phase III (2007-2012), prevention of parent to child transmission(PPTCT) has been given due importance.

According to HIV Sentinel surveillance (2014-2015) by the NACO, the overall HIV prevalence is $0.29 \%$ among ANC clinic attendees. ${ }^{1}$ While HIV in pregnant women in this part of North India i.e. Uttar Pradesh is $0.21 \%{ }^{8}$ So, if we estimate seroprevalence in pregnancy, the effective and timely intervention will reduce the transmission of infection to new born babies. ${ }^{9}$

To the best of our knowledge, only few studies on HIV prevalence in antenatal women are available from Uttar Pradesh India, hence we undertook this study to determine the trend of HIV seroprevalence among pregnant women attending antenatal clinics at tertiary Care Hospital of Uttar Pradesh, India.

\section{METHODS}

All pregnant women registered at antenatal clinic of GSVM Medical College, Kanpur, Uttar Pradesh, India. from September 2005 to July 2016, were enrolled as the study population. All pregnant women attending antenatal clinic routinely advised to undergo HIV screening after pre-test counselling and informed consent. Our laboratory provided HIV antibodies testing facilities to all such patients and tests were carried out as per the guidelines led down by the NACO, India and no selection bias was observed. HIV antibodies were tested by the three antigenically different kits as per the guidelines led down by the World Health Organization (WHO testing strategy III) and GOI and positive test results were disclosed only after post- test counselling of the patient. ${ }^{10}$

Partner testing was offered in seropositive women. Posttest counselling included information about MTP services and women who opted to continue pregnancy, were asked to come for regular follow up by obstetrician and physician, ART was advised and counselling was done for institutional delivery.

\section{RESULTS}

A total of 38794 antenatal women registered in department of Obstetrics \& Gynecology, GSVM Medical College, Kanpur, Uttar Pradesh, India for period of approximately 11 years from September 2005 to July 2016 were included in this study. Out of these 34924 $(90.02 \%)$ women were ready for testing after counselling. Overall 102 women were found to be seropositive for HIV-I antibodies with a seroprevalence rate of $0.3 \%$. No pregnant women were seropositive for HIV-2 antibodies (Table 1).

Table 1: Total ANC women counselled and tested at PPTCT from 2005-2016 at tertiary care hospital of Uttar Pradesh, India.

\begin{tabular}{|c|c|c|c|}
\hline $\begin{array}{l}\text { Total no. of ANC } \\
\text { counselled }\end{array}$ & Total no. of ANC tested (\%) & $\begin{array}{l}\text { Total no. of HIV } \\
\text { positives }\end{array}$ & $\begin{array}{l}\text { Percentage }(\%) \text { of } \\
\text { seropositivity }\end{array}$ \\
\hline 38794 & $34924(90.02 \%)$ & 102 & 0.30 \\
\hline
\end{tabular}

All pregnant females were married and majority of them were Hindu $(88.2 \%)$ by religion, from rural area $(67.6 \%)$, studied up to primary $(39.2 \%)$ or secondary $(39.2 \%)$ and belongs to low socio-economic status $(74.5 \%)$.

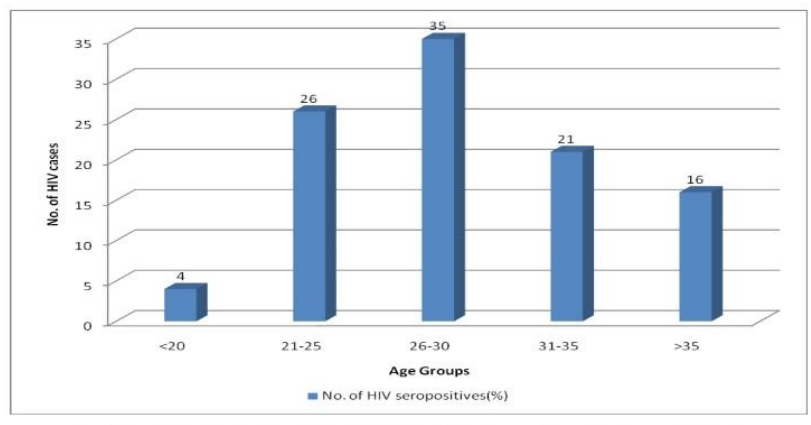

Figure 1: Age wise distribution of HIV cases as proportion of total population.
Most of them were multigravida $(62.7 \%)$, housewife by occupation $(89.2 \%)$ and husbands of $55.9 \%$ seropositive women were found reactive (Table 2).

Majority of antenatal women (41.6\%) were in age group of 26-30 years and least in the age group of less than 20 years (1.5\%). Amongst seropositive women, majority $(34.3 \%)$ were in age group of 26 to 30 years followed by the age group of 21 to 25 years $(25.4 \%)$ and only 4 women $(3.9 \%)$ below 20 years of age were found seropositive. The youngest HIV seropositive female was aged 18 years, while the oldest was 38 years. (Figure 1)

HIV seropositivity was highest at $0.78 \%$ in younger female under 20 years of age followed by $0.49 \%$ in female more than 35 years of age. In the age group, 21 to 25 years, 26 to 30 years, 31 to 35 years seropositivity was $0.22 \%, 0.24 \%, 0.46 \%$ respectively (Table 3 ) (Figure 2 ). 


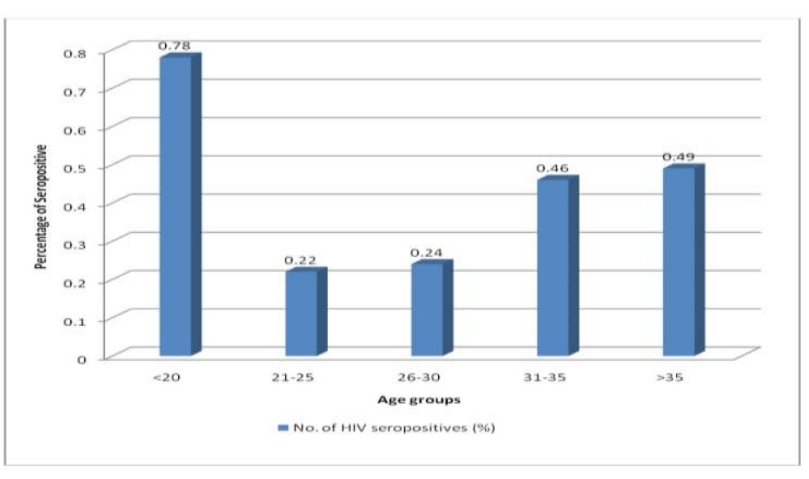

Figure 2: Age specific prevalence of the HIV among pregnant women.
A year wise analysis depicts that in 2005 only 41 pregnant women tested for HIV because HIV testing was started in the month of September and no patient was found to be seropositive. The percentage of HIV testing was gradually increased thereafter. The HIV seroprevalence rates showed an increasing trend from $0.14 \%$ in 2006 to $0.49 \%$ in 2016 (till July). Prevalence of HIV in antenatal women was highest in 2016 followed by 2009 and 2010 i.e. $0.49 \%, 0.41 \%$ \& $0.41 \%$ respectively. Lowest prevalence was noted in 2007 i.e., $0.09 \%$ but in that year less number of women only 1344 were tested for HIV. However, the overall prevalence remained $0.3 \%$ (Table 4) and trend of HIV seroprevalence over a period of eleven years (September 2005 to July 2016) is representing in graphical form in Figure 3.

Table 2: Demographic characteristics of seropositive antenatal women at tertiary hospital of Uttar Pradesh, India.

\begin{tabular}{|c|c|c|c|}
\hline \multicolumn{2}{|c|}{ Demographic characteristics $(n=102)$} & \multirow{2}{*}{$\begin{array}{l}\text { No of seropositives } \\
102 \\
0\end{array}$} & \multirow{2}{*}{$\begin{array}{l}\text { Percentage (\%) } \\
100 \%\end{array}$} \\
\hline Marital status & $\begin{array}{l}\text { Married } \\
\text { Unmarried }\end{array}$ & & \\
\hline Religion & $\begin{array}{l}\text { Hindu } \\
\text { Muslims } \\
\text { Others }\end{array}$ & $\begin{array}{l}90 \\
09 \\
03\end{array}$ & $\begin{array}{l}88.2 \% \\
8.9 \% \\
2.9 \%\end{array}$ \\
\hline Residence & $\begin{array}{l}\text { Rural } \\
\text { Urban }\end{array}$ & $\begin{array}{l}69 \\
33\end{array}$ & $\begin{array}{l}67.6 \% \\
32.4 \%\end{array}$ \\
\hline Education & $\begin{array}{l}\text { Illiterate } \\
\text { Primary } \\
\text { Secondary } \\
\text { Graduate }\end{array}$ & $\begin{array}{l}10 \\
40 \\
40 \\
12\end{array}$ & $\begin{array}{l}9.8 \% \\
39.2 \% \\
39.2 \% \\
11.8 \%\end{array}$ \\
\hline Occupation & $\begin{array}{l}\text { housewife } \\
\text { Labourer } \\
\text { Service }\end{array}$ & $\begin{array}{l}91 \\
06 \\
05\end{array}$ & $\begin{array}{l}89.2 \% \\
5.9 \% \\
4.9 \%\end{array}$ \\
\hline Socio-economic status & $\begin{array}{l}\text { Upper } \\
\text { Middle } \\
\text { Lower middle } \\
\text { Upper lower } \\
\text { Lower }\end{array}$ & $\begin{array}{l}0 \\
0 \\
26 \\
36 \\
40\end{array}$ & $\begin{array}{l}25.5 \% \\
35.3 \% \\
39.2 \%\end{array}$ \\
\hline Gravidity & $\begin{array}{l}\text { Primi } \\
\text { Multi }\end{array}$ & $\begin{array}{l}38 \\
64\end{array}$ & $\begin{array}{l}37.3 \% \\
62.7 \%\end{array}$ \\
\hline Husband status & $\begin{array}{l}\text { Reactive } \\
\text { Non-reactive } \\
\text { Dead } \\
\text { Not done }\end{array}$ & $\begin{array}{l}57 \\
30 \\
08 \\
07\end{array}$ & $\begin{array}{l}55.9 \% \\
29.4 \% \\
7.8 \% \\
6.9 \%\end{array}$ \\
\hline
\end{tabular}

Table 3: Age distribution of HIV seroprevalence among antenatal women at tertiary care hospital of Uttar Pradesh, India.

\begin{tabular}{|c|c|c|c|c|}
\hline $\begin{array}{l}\text { Age group } \\
\text { (years) }\end{array}$ & $\begin{array}{l}\text { No. of ANC women } \\
\text { tested }(\%)\end{array}$ & $\begin{array}{l}\text { No. of HIV } \\
\text { seronegatives }\end{array}$ & $\begin{array}{l}\text { No. of HIV } \\
\text { seropositives (\%) }\end{array}$ & $\begin{array}{l}\text { Percentage of } \\
\text { seropositivity }(\%)\end{array}$ \\
\hline$<20$ & $515(1.5 \%)$ & 511 & $4(3.9 \%)$ & $0.78 \%$ \\
\hline $21-25$ & $12031(34.4 \%)$ & 12005 & $26(25.5 \%)$ & $0.22 \%$ \\
\hline $26-30$ & $14516(41.6 \%)$ & 14481 & $35(34.3 \%)$ & $0.24 \%$ \\
\hline $31-35$ & $4597(13.2 \%)$ & 4576 & $21(20.6 \%)$ & $0.46 \%$ \\
\hline$>35$ & $3265(9.3 \%)$ & 3249 & $16(15.7 \%)$ & $0.49 \%$ \\
\hline Total & 34924 & 34822 & 102 & \\
\hline
\end{tabular}


Table 4: Year wise prevalence rate of HIV in antenatal women at tertiary care hospital of U.P, India

\begin{tabular}{|c|c|c|c|c|}
\hline Year & $\begin{array}{l}\text { Total ANC } \\
\text { counselling }\end{array}$ & Total ANC testing (\%) & ANC HIV positive & ANC hivpositivity (\%) \\
\hline $2005^{*}$ & 620 & $41(6.6 \%)$ & 0 & \\
\hline 2006 & 1911 & $1344(70.3 \%)$ & 02 & 0.14 \\
\hline 2007 & 2378 & $2110(88.7 \%)$ & 02 & 0.09 \\
\hline 2008 & 3088 & $2442(78.4 \%)$ & 04 & 0.16 \\
\hline 2009 & 4182 & $4182(100 \%)$ & 17 & 0.41 \\
\hline 2010 & 4234 & $3942(93.1 \%)$ & 16 & 0.41 \\
\hline 2011 & 4608 & $3798(82.4 \%)$ & 07 & 0.18 \\
\hline 2012 & 4117 & $3735(90.7 \%)$ & 08 & 0.21 \\
\hline 2013 & 3815 & $3492(91.5 \%)$ & 13 & 0.37 \\
\hline 2014 & 3173 & $3170(99.9 \%)$ & 11 & 0.34 \\
\hline 2015 & 4226 & $4226(100 \%)$ & 10 & 0.23 \\
\hline $2016 * *$ & 2442 & $2442(100 \%)$ & 12 & 0.49 \\
\hline Total & 38794 & $34924(90.02 \%)$ & 102 & 0.30 \\
\hline
\end{tabular}

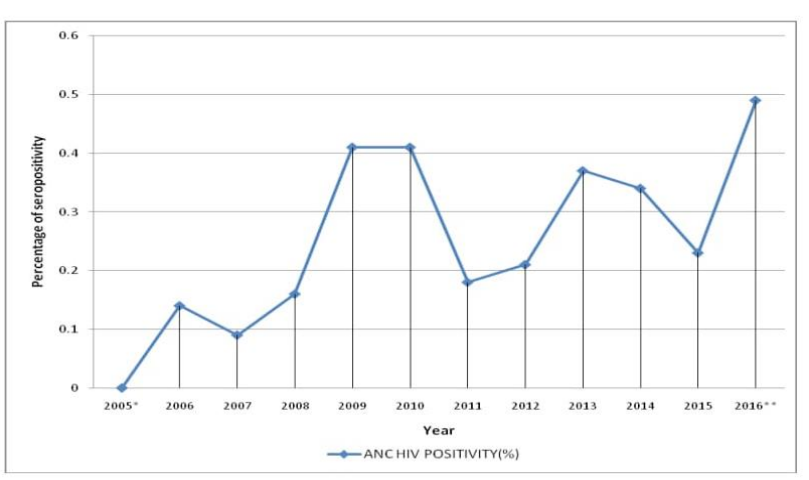

Figure 3: Trend of seropositivity over a period of 11 years

\section{DISCUSSION}

This retrospective study represents that the overall HIV seroprevalence among antenatal women for past eleven years was $0.3 \%$ and total HIV testing in last 11 years by opt out approach was $90.02 \%$ and for last 3 years it is almost $100 \%$. In opt out approach, pregnant women are told that an HIV test will be included in the standard group of prenatal tests and they may decline the test. Center for disease control (CDC) also recommends opt out approach as the testing rate is $85-98 \% .^{11}$

According to the studies done by Parameshwari et al, Joshi et al, Sinha et al, Chaudhari et al and Dash et al; the acceptance of HIV testing by opt out approach was $100 \%, 83 \%, 79 \%, 96 \%$ and $84 \%$ respectively.,12-15 This emphasizes that by good HIV counselling acceptance rate can increase up to $100 \%$ as occurs in last 3 years of present study.
We observed that all seropositive women were married $(100 \%)$, majority of them were Hindu by religion $(88.2 \%)$, resident of rural areas $(67.6 \%)$ belongs to low socioeconomic status $(74.5 \%)$, housewife by occupation $(89.2 \%)$ which is comparable to the study done by Dash et al, in which most of the women were married $(99.05 \%)$, Hindu by religion $(96.2 \%)$, resident of rural area $(73.3 \%)$ with low socioeconomic status $(76.19 \%)$ and $87.6 \%$ women were housewife by occupation. ${ }^{15}$ Similarly in study done by Mehrotra et al, majority of seropositive women were Hindu $(75 \%)$, belongs to rural area $(66.5 \%)$ and had low socioeconomic status $(66.5 \%){ }^{16}$

According to present study majority of the women were multigravida and studied up to primary or secondary in contrast to study done by Dash et al and Patil et al where most of the women were primigravida and was either illiterate or studied up to primarylevel..$^{15,17}$ In this study, multigravida were found to be more infected as they were more exposed to infection. Whereas Perry et al state that there is no significant difference between seropositive and seronegative women regarding socioeconomic status, residence and religion. ${ }^{18}$ In this study, reason for high seropositivity in low socioeconomic status and rural areas may be due to lower level of education, inadequate personal hygiene, poor access to health care facilities, high prevalence of STD and sexual promiscuity among them.

In present study husbands of $57(55.9 \%)$ females were found positive and $30(43.6 \%)$ were negative for HIV infection. Status was not known of 15 husbands in which 8 were dead and 7 were not ready for testing even after counselling. Major cause of discordant couple was sexual promiscuity $(73.3 \%)$ in females. Hence main route of transmission of infection was heterosexual contact. 
To compare higher percentage of husbands were found seropositive $(96.59 \%)$ in study done by Ukey et al and less number of husbands were seroreactive i.e. $44 \%$ in study done by Malik et al. ${ }^{19,20}$

The age wise distribution showed a higher predisposition of infection in young age group being maximum in age group of $26-30(34.3 \%)$ followed $21-25$ years $(25.4 \%)$ and least in age group $<20$ years. (3.9\%). Present observation is consistent with study done by Dash et al where HIV infection was highest in the age group of 2529 years $(43.8 \%)$, followed by $20-24$ years $(33.34 \%){ }^{15}$ But in studies done by Ukey et al, Malik et al, Gupta et al and Garg et al; HIV infection was highest in age group $<24$ years. ${ }^{19-22}$

It may be because of the fact that 20 to 30 years is the most sexually active age group. High prevalence in this group can be an alarming sign as there is more chance of spread of infection and loss of youth may cause both social and financial burden for the nation. This also suggests that there was a higher awareness about HIV among married women of younger age group. Even Palikadavath et al showed that HIV awareness among North Indian married women was higher in 15-24 years age group as compared to older women. ${ }^{23}$

However, on calculating the age specific prevalence, we found that higher seropositivity was observed among age group $<20$ years $(0.78 \%)$ and the women having age $>35$ years $(0.49 \%)$. This can be explained by the fact that the total number of women tested in these age groups were less as compared to pregnant women screened in age ranging between 20-35 years.

According to HIV sentinel surveillance (2014-15), the overall HIV prevalence among antenatal attendees is $0.29 \%$ in India. In present study, the overall prevalence was $0.30 \%$ calculated over a period of approximately 11 years (September2005-July 2016) which is slightly higher than prevalence of HIV in pregnant female at national level but much higher than prevalence of HIV in pregnant women in this part of North India i.e. Uttar Pradesh which is $0.21 \% .^{8}$ In comparison to other studies of Uttar Pradesh; higher seroprevalence of $0.4 \%$ were observed by Mehrotra et al in $2003-2004,0.41 \%$ by Malik et al in 2011-2013 and $0.58 \%$ by Garg et al in 2005-2015. ${ }^{16,20,22}$

In study done by Gupta et al in AIIMS Delhi, India, prevalence was found to be $0.88 \% .{ }^{21}$ Studies from south India by Giri et al, Sarkate et al, Ashatagi et al and revealed prevalence of $0.41 \%, 0.88 \%$ and $0.70 \%$ respectively. ${ }^{24-26}$ Three studies from Maharashtra, by Patil VM et al (2004-2013), Ukey et al and Kulkarni et al (2007-11) reported prevalence of $0.44 \%, 1.38 \%$ and $0.76 \%$ respectively. ${ }^{18,20,27}$ Similarly higher seroprevalence of $0.77 \%$ by Parmeshwari et al in 2009, $0.35 \%$ by Joshi et al in $2010,0.41 \%$ by Sinha et al in $2008,0.66 \%$ by Dash et al in $2005-2012$, of $0.72 \%$ by Nagdeo et al in 2007 were noted in several studies from

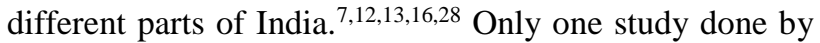
Chaudhari et al in 2010 observed lower seroprevalence of $0.17 \%$ in comparison to the present study. ${ }^{14}$

While analysing the trend, we detected a rise in the HIV seroprevalence rate from 0.14 in 2006 to 0.49 in 2016 (till July). Even though less number of women were tested in 2006 as compared to 2016, still trend indicate concern. Similarly, in study done by Gupta et al, a rise in the HIV seroprevalence rate from $0.7 \%$ in $2003-2004$ to $0.9 \%$ in 2005-2006 was found. ${ }^{21}$ Shyamala et al also observed a rising trend from $0.2 \%$ in 1997 to $1.4 \%$ in $2001 .^{29}$ In contrast, other studies done by Parmeshwari et al, Dash et al, Patil et al, Garg et al, Kulkarni et al and Maitra et al, a decreasing trend of HIV seroprevalence was reported. $7,15,17,22,27,30$

Analyzing the reason for this difference between our results and NACO data, could be different surveillance system. Present study is hospital based survey for past 11 years while NACO uses sentinel surveillance system and being a tertiary centre, most of seropositive HIV women are referred from several centers, so higher number of seropositive antenatal women are attended in our hospital.

However, the seroprevalence in our study is less than the national data. but as Uttar Pradesh comes under low prevalence region and prevalence of $0.3 \%$ against $0.21 \%$ for the state, rings a bell because Uttar Pradesh occupies $16 \%$ of total population of India and population of Uttar Pradesh in 2015 was around 215 millions and a mere $0.1 \%$ increase in the prevalence rate will rise the number of persons living with HIV in lakhs. ${ }^{31}$ Hence it is high time for strengthening \& implementation of PPTCT and intervention programs such as HIV awareness \& safe sex education in each and every corner of the state.

\section{CONCLUSION}

Present study indicates an increasing trend of HIV prevalence and seroprevalence of HIV infection among antenatal women in northern India is $0.3 \%$ which is lower than the national projection but much higher as compared to data of Uttar Pradesh and age group 26-30 years was found to be most affected age group.

However, this study being a hospital based study with limited sample size so this study is not true representative of entire north India but definitely provides a glimpse of present situation. So, this is the time for increasing awareness about HIV and for implementation of mandatory counselling and testing of HIV by joint efforts of public and private sector before it is too late and pregnant state provides best time for screening and implementation of PMTCT program thereby reduction in HIV infection and AIDS. Timely detection and effective counselling can help to control disease progression and can prevent vertical transmission of HIV infection to present and future generations. 
Funding: No funding sources

Conflict of interest: None declared

Ethical approval: The study was approved by the Institutional Ethics Committee

\section{REFERENCES}

1. National AIDS Control Organization (NACO), Government of India (GOI) Annual Report 2015-16. http://www.nacoonline.org. Accessed 2006.

2. Kumar R, Jha P, Arora P, Mony P, Bhatia P, Millson $\mathrm{P}$, et al. Trends in HIV-1 in young adults in South India from 2000 to 2004. A prevelance study. Lancet. 2006;367(9517):1164-72.

3. Zaba B, Boerma T, White R. Monitoring the AIDS epidemic using HIV prevalence data among young women attending antenatal clinics: Prospects and problems. AIDS. 2000;14:1633-45.

4. Boerma JT, Ghys PD, Walker N. Estimates of HIV-1 prevalence from national population based surveys as a new gold standard. Lancet. 2003;362:1929-31.

5. Srikanth P, John TJ, Jeyakumari H, Babu PG, Mathai $\mathrm{D}$, Jacob M, et al. Epidemiological features of acquired immunodeficiency syndrome in Southern India. Indian J Med Res. 1997;105:191-7.

6. Indian Council of Medical Research. National Institute of Medical Statistics. National AIDS Control Organization. Technical report- India HIV estimates- 2006, New Delhi, ICMR, 2006.

7. Parmeshwari S, Jacob MS, Vijayakumari JJ, Shalini D, Sushi MK, Shiv MR. A programme on prevention of mother to child transmission of HIV at government hospital at Tiruchengode Taluka, Namakkal District. Indian $\mathrm{J}$ Commun Med. 2009;34:261-3.

8. HIV AIDS Statistics 2010-2011 [http:// www.avert.org/india-hiv-aids - statistics.htm.

9. Kaur M, Mittal A, Kaur K. HIV infection and obstetrics. J Applied Med. 1994;4:295-300.

10. Baveja UK. HIV Antibody Testing with special reference to HIV-1. In: HIV testing Manual, Laboratory diagnosis, bio safety and Quality control. National AIDS Control organization: New Delhi:4567.

11. Chaudhuri S, Bose S, Talukdar A, Ghosh US. Seroprevalence and utilization of therapeutic intervention in PPTCT services in a teaching hospital in Kolkata. J Obstet Gynecol India. 2007;57:251-6.

12. Joshi U, Kadri A, Bhojiya S. Prevention of parent to child transmission services and interventionscoverage and utilization: A cohort analysis in Gujarat, India. Indian J Sex Transm Dis. 2010;31(2):92-8.

13. Sinha A, Roy M. An ICMR task force study of Prevention of parent to child transmission (PPTCT) service delivery in India. Indian J Public Health. 2008;52:200-2.

14. Chaudhary S, Mundle M, Konar H, Das C, Talukdar A, Ghosh US. Utilization of therapeutic intervention to prevent mother to child transmission of HIV in a teaching hospital in Kolkata, Indian J Obstet Gynecol Res. 2010;36:619- 25.

15. Dash M, Mohanty I, Sahu S, Narasimham M, Padhi S, Panda P. Declining HIV seroprevalance among pregnant women in South Odisha, India: A six and half years tertiary care hospital based study. Int J Biomed Adv Res. 2012;03(07):546-51.

16. Mehrotra R, Pourush S, Bhargava A, Varma M, Ghosh UK. Seroprevelance of HIV in antenatal women. J Obstet Gynecol India. 2005;55(4):333-5.

17. Patil VM, Moray AP, Patil SP. Ten years trend of HIV seroprevalence among Indian pregnant women attending antenatal clinic at tertiary hospital in Dhule, Maharashtra, India. Int J Reprod Contracept Obstet Gynecol. 2016;5(5):1514-19.

18. Perry D, Reid M, Thame M, Fletcher H, Mullings A, McCaw-Binns A. Human immunodeficiency virus infection seroprevalence and risk factor study among pregnant women attending the Antenatal clinic at the University hospital of the West Indies, Kingston. Jamaica. West Indian Med J. 2002;51(2):80-3.

19. Ukey PM, Akulwar SL, Powar RM. Seroprevalence of Human immunodeficiency virus infection in pregnancy in a tertiary care hospital. Indian J Med Sci. 2005;59:382-7.

20. Malik A, Sami H, Khan PA, Fatima N, Siddiqui M. Prevalence of human immunodeficiency virus infection in Pregnant women and birth outcome at Tertiary Care Centre in a North Indian town. J Immunol Vaccine Tech. 2015;1(1):104.

21. Gupta S, Gupta R, Singh S. Seroprevalence of HIV in pregnant women in North India. BMC Infectious diseases. 2007;7:133.

22. Garg R, Singh S, Singh S, Sarin I, Kumar S. Prevelance of HIV infection in pregnancy at a referral Health Centre of India: 10 Years data. Int J Curr Res Aca Rev. 2016;4(2):131-9.

23. Pallikadavath S, Jayachandran AA, Stones RW. Women's Reproductive Health, Socio cultural context and AIDS knowledge in Northern India. J Health Manag. 2005;7(1):109-28.

24. Giri P, Bangal V, Phalke D. Prevelance of HIV among rural pregnant women attending antenatal clinics at Pravara Rural Hospital, Loni, Maharashtra, India. Int J Health Allied Sci. 2012;1(1):13-5.

25. Sarkate $P$, Paranjpe $S$, Ingole $N$, Mehta $P$. Monitoring HIV epidemic in pregnant women: are the current measures enough? J Sex Transm Dis. 2015:194331,5.

26. Ashatagi GS, Metgud CS, Welvekar PR, Naik VA. Prevalence of HIV among rural pregnant women attending PPTCT services at KLE Hospital, Belgaum. Al Ameen J Med Sci. 2011;4:45-8.

27. Kulkarni SK, Doibale MK. Trend of seroprevalence of HIV among antenatal clinic attendees at a tertiary care hospital. International Journal of Basic and Applied Medical Sciences. 2013;3(1):257-62.

28. Nagdeo N, Thombare VR, Prevention of parent-tochild transmission of HIV: an experience in rural population. Indian J Med Microbiol. 2007;25:425. 
29. Shyamala G, Kushtagi P, Madhushri VB. Seropositivity for Human Immunodeficiency Virus in pregnancy in a tertiary care hospital in south west India. Ind Pract. 2004;57:649-52.

30. Maitra N, Kavishvar B, Dinkar A, Desai VA. Antenatal HIV testing. J Obstet Gynecol India. 2006;56:56-58.
31. Population of Uttar Pradesh- India Guide. www.indiaonlinepages.com population.

Cite this article as: Dwivedi S, Jahan U, Srivastava R, Agnihotri A. Trend of HIV seroprevalence among antenatal women at tertiary care hospital in North India, eleven years retrospective study. Int J Reprod Contracept Obstet Gynecol. 2017;6:537-43. 